\title{
Preschool Teaching Staff's Opinions on the Importance of Preschool Curricular Fields of Activities, Art Genres and Visual Arts Fields
}

Tomaž ZupanČIČ ${ }^{* 1}$, BRAnKa ČAgRAN ${ }^{2}$, ANd Matjaž Mulej ${ }^{3}$

$\approx \quad$ This article presents preschool teachers' and assistant teachers' opinions on the importance of selected fields of educational work in kindergartens. The article first highlights the importance of activities expressing artistic creativity within modern curriculums. Then, it presents an empirical study that examines the preschool teachers' and assistant teachers' opinions on the importance of the educational fields, art genres, and visual arts fields. In research hypotheses, we presumed that preschool teachers find individual educational fields, individual art genres, and individual visual arts activities to be of different importance; consequently, education in kindergarten does not achieve the requisite holism. The study is based on the descriptive and causal-non-experimental method. We have determined that the greatest importance is attributed to movement and language, followed by nature, society, art and mathematics. Within art genres, the greatest importance is attributed to visual arts and music and the least to audio-visual activities. Within visual arts, drawing and painting are considered to be the most important and sculpting the least. These findings can support future studies and deliberation on the possible effects on practice in terms of requisitely holistically planned preschool education.

Keywords: curriculum, preschool education, preschool teachers, requisite holism, visual arts activities

$1 \quad{ }^{*}$ Corresponding Author. Faculty of Education, University of Maribor, Slovenia; tomaz.zupancic@um.si

2 Faculty of Education, University of Maribor, Slovenia

3 Faculty of Economics and Business, University of Maribor, Slovenia 


\section{Vrednotenje pomembnosti kurikularnih področij dejavnosti, umetnostnih zvrsti in likovnih področij med predšolskimi pedagoškimi delavci}

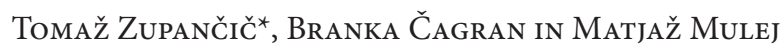

$\propto$ Prispevek predstavlja mnenja predšolskih pedagoških delavk (vzgojiteljic in pomočnic vzgojiteljic) o pomembnosti posameznih področij vzgojnega dela v vrtcu. Najprej osvetlimo pomembnost izrazno ustvarjalnih dejavnosti znotraj sodobnih kurikulumov. V nadaljevanju predstavimo empirično raziskavo, ki zajema mnenja vzgojiteljic in pomočnic vzgojiteljic o pomembnosti vzgojnih področij, umetnostnih zvrsti in likovnih področij. V raziskovalnih hipotezah smo predvideli, da vzgojiteljice in pomočnice vzgojiteljic različno vrednotijo pomembnost vzgojnih področij, umetnostnih zvrsti in likovnih področij. Raziskava temelji na deskriptivni in kavzalno-neeksperimentalni metodi. Ugotovili smo, da se največji pomen pripisuje gibanju in jeziku, sledijo pa narava, družba, umetnost in matematika. Znotraj umetnostnih zvrsti se največja pomembnost pripisuje likovnim in glasbenim dejavnostim, najmanjša pa avdiovizualnim. Znotraj likovnih področij sta za vzgojiteljice in pomočnice vzgojiteljic najpomembnejša risanje in slikanje, najmanj pomembno pa je področje kiparstva. Spoznanja raziskave lahko predstavljajo osnovo za naslednje študije in razmisleke o mogočih vplivih na prakso v smeri uresničevanja primerno celovito zasnovane predšolske vzgoje.

Ključne besede: kurikulum, predšolska vzgoja, vzgojitelj, zadostna in potrebna celovitost, likovne dejavnosti 


\section{Introduction}

Art genres are of crucial importance in the preschool curriculum, which determines the content and work objectives in kindergarten. The fields determined by the Slovenian Curriculum for Kindergartens (Bahovec et al., 1999) are language, movement, nature, society, art, and mathematics. In planning and implementing actual activities, these fields should be represented as equally intertwined; they should supplement one another. Martin-Kniep, Feige and Soodak (1995) define such interdisciplinary connections as an example of holistic learning and integration that is derived from the complexity of the world, bridges the boundaries between the disciplines and, therefore, supports the holistic development of the child. The UNICEF publication Programming Experiences in Early Child Development (UNICEF, 2006) emphasizes that "A holistic approach to Early Child development, first and foremost, is the child's right" (p. 3), and states, "that this approach has been shown to be effective" (p. 4). A holistic approach and integrated approach to learning and intertwining of fields are important parts of different preschool curricula (Bose, 2010; Ministry of Education, 2012; Government of Saskatchewan, 2013; Devarakonda, 2013, etc.).

The importance of the intertwining of fields also lies at the core of the Slovenian Curriculum for Kindergartens:

The term curriculum in the kindergarten was implemented as it is a broader and more comprehensive term than programme and as it represents a shift from the traditional emphasis on the content to the emphasis on the process of preschool education, on the complexity of interactions and experience that children learn from (Bahovec et al., 1999, p.3).

One of the objectives of the curriculum is the "balanced offer of diverse fields and activities of preschool education in kindergartens" (Bahovec et al., 1999, p. 5). The curriculum-based principle of balance recommends that preschool teachers should provide diverse activities and facilitate all aspects of the child's development (Marjanovič Umek et al., 2011). It is important that the activities from different fields and thus the different aspects of the child's development and learning be horizontally linked, as it is especially characteristic of children that the aspects of their development are co-dependent and interlinked (Bahovec et al., 1999).

The individual fields of development are intertwined, as different psychological functions run parallel to each other and are connected (e.g. the child perceives, experiences and gets to know himself, the world surrounding him, different relationships from the emotional, intuitive, social and cognitive 
aspect). Subject-specific objectives and individual activities in the kindergarten curriculum have to be read as an aid in the planning of concrete activities, which have to cover all areas of the child's development as equally as possible following the general principle of balance (Kroflič, 2001). Such intertwining, including art education, should lead to increased comprehension and requisite holism, which is more realistic than holism because it includes all and only essential viewpoints rather than all existing ones that are included in the concept of holism, which cannot be attained by human beings, not even in an interdisciplinary creative cooperation (Mulej \& Kajzer, 1998, based on Mulej, 1979). The importance of art education is not emphasized only by art teachers, gestalt (i.e. holistic) psychologists and researchers of creativity, but also by general educators and educationalists.

The White Paper on Education (Krek \& Metljak, 2011) emphasizes that achievements in important knowledge fields, which also includes different artistic fields, are usually not included in international studies of knowledge (TIMSS, PISA, PIRLS), even though they are an important part of knowledge and education. We also need to strive towards excellence in these fields (visual arts, music, etc.) (Krek et al., 2011).

\section{The importance of art education}

European policy is attempting to introduce more artistic content into school curricula: knowing and understanding art, critical evaluation, understanding the importance of cultural heritage (Ivon \& Kuščević, 2013), understanding cultural diversity, abilities to express and develop one's identity through art and creativity are the fundamental objectives of cultural and art education (Bračun Sova \& Kemperl, 2012). Kroflič (2007) emphasizes the educational value of the aesthetic experience in education.

The key dimensions of an artistic experience, which ensure its status as one of the authentic forms of an individual's entry into relationships with his/her environment and his/her realisation of the truth of his/her own being are imagination, metaphor and narration [...] Engaging in art turned out to belong to the most efficient tools, not only for an individual's personal development, but also for ensuring quality of life (Kroflič, 2007, p. 27).

Artistic expression enables the child to develop various potentials: creativity, imagination, conceivability, sensitive perception, and conceptions. Early education is known for its creative approach (Jeffrey \& Craft, 2004); 
furthermore, art activities are important activities in which "the relation between teaching creatively and teaching for creativity is an integral one" (Jeffrey \& Craft, 2004, p. 84). Art supports the multi-layered development of a child's cognition, from the coherence of adopted knowledge (i.e. the ability to connect parts into appropriately holistic realizations and actions), knowledge, and skills, to the development of imagination and aesthetic feelings (Efland, 2002).

Visual arts function in much the same way. Visual arts activities develop a child's understanding of the space that he/she inhabits. This comprehension of space is complex and intertwined. It encompasses, firstly, the three-dimensional Euclidian space and its symbolic representations on the surface. It also encompasses the social and cultural space that surrounds us. Visual arts activities also support the development of visual thinking (Arnheim, 2009), i.e. that part of thinking that deals with the visual: spatial relationships, distance, and overlapping. Visual arts activities enhance the development of the ability to communicate with the language of visual arts: colour and form relationships, compositions, rhythms, contrasts, and proportions (Didek, 1982; Butina, 1997; Eisner, 2002). Also supported are components of general development that enrich the child's emotional viewpoint and intelligence, develop divergent thinking, and contribute to the child's social, ethical and moral development (Herne, Cox, \& Watts, 2009; Hickman, 2010).

Contemporary art education studies emphasize the importance of an early introduction into the world of art, the importance of scheduled planning, content planning (Lindstrom, 2011), understanding the process of learning art and being educated in art, and conducting studies in art education (Hickman, 2008; Addison, Burgess, Steers, \& Trowell, 2010). Getting to know art should be requisitely holistic and therefore intertwined.

In Slovenian compulsory schools' syllabi, the time devoted to art (music, visual arts, and literature) is determined by the number of hours that are allocated to individual subjects, which, formally, also determines their importance and intertwining. The Slovenian Curriculum for Kindergartens is designed as an open syllabus (Kroflič, 2001; Zupančič, 2008). It provides directions for content and objectives for individual fields but not the number of daily or weekly hours. The frequency of teaching a field depends on preschool teachers; "a substantial share of direct professional decisions is of course transferred to the level of the kindergarten principals and the individual teacher, which is planned to lead to even more active innovations in public kindergartens in the future" (Kroflič, 2001, p. 24). Achieving the requisite holism thus largely depends on the requisite personal holism (Šarotar Žižek, 2012) of teachers and assistant teachers, as well as kindergartens' principals and kindergarten children's parents. 
The number of individual activities, accordingly, depends on preschool teachers' inclinations toward individual fields of the curriculum. It stems from the teachers' 1) belief in the relative importance of fields within the curriculum, 2) the individual's level of qualification for implementing a field, and 3) personal affinities for individual fields. An additionally important question relates to their inclination towards the intertwining of fields. In open curriculum systems, teachers' opinions are, thus, even more important. In a previous study (Zupančič, 2012), we established that preschool teachers find environmental problems, which relate to protecting the environment and preserving natural resources, to be very important. They place them above the economic, political, and health issues of modern society. Hence, one may conclude they teach environmental content more frequently than visual arts.

Garvis and Pendergast (2011) studied the qualifications of preschool teachers for teaching individual art genres. They first emphasize that every preschool teacher is responsible for the daily implementation of visual arts activities. They further quote UNESCO's guidelines (Road Map for Arts Education, 2006) that especially emphasize the importance of art education. They note that art education is an essential component of general education; it requires appropriately qualified teachers. Their study (covering Australian preschool teachers) showed that more than $50 \%$ of respondents did not feel qualified to implement art activities, especially visual arts and music. Only $14 \%$ felt they were completely qualified and competent to implement music activities. No single teacher felt qualified to implement visual arts activities.

Denac (2010) studied Slovenian preschool teachers' perceptions of the importance of individual educational fields, specifically the teachers' interest in implementing various activities from the kindergarten curriculum. She established that teachers ranked these activities as follows (from the most to the least preferred): language, art, movement, nature, mathematics, and society. Within art, teachers expressed the highest interest in visual art, followed by music, dance, drama, and finally audio-visual activities (Denac, 2010). She did not investigate the intertwining of fields.

\section{The importance of the intertwining of fields}

Intertwining matters: it trains learners for connective observance, which supplements unavoidable, narrow specialization in a field, and helps people (in this case, teachers and children) perceive the broadness of influences and their connections that run into team synergies. Here are a few extreme examples: individually, sodium and chlorine are dangerous poisons, but in synergy they 
make edible salt; hydrogen and oxygen are gases, but together they make water; together the bee and the flower give us honey, as they are co-dependent, and their lives are thus intertwined. Let us stress again: total holism, which many recklessly use the term "holism", cannot be achieved in human thinking and actions: it would completely cover all aspects, all connections between them and all synergies. Nature and life are too complex for the total holism of human insight, so people have always specialized in knowing: to understand/master a specific part of life-practice. The saying "my knowledge covers but a drop in the ocean, nothing more" applies; therefore, "one hand washes the other, both wash the face". Limiting the holism of approaches to a single chosen aspect is the other extreme, which is necessary for specialization, but also dangerous: it assumes that the ocean surrounding our drop does not exist or is at least not important or deserving our attention. This is obviously not correct. The middle way between the two extremes is the dialectical system as an intertwining of all essential and only essential viewpoints; it enables the requisite holism (Mulej, 1974; Mulej \& Kajzer, 1998). What people choose to deem essential and what they leave aside as less essential or even completely unessential and unconsidered is the responsibility of the people making the choice (Figure 1).
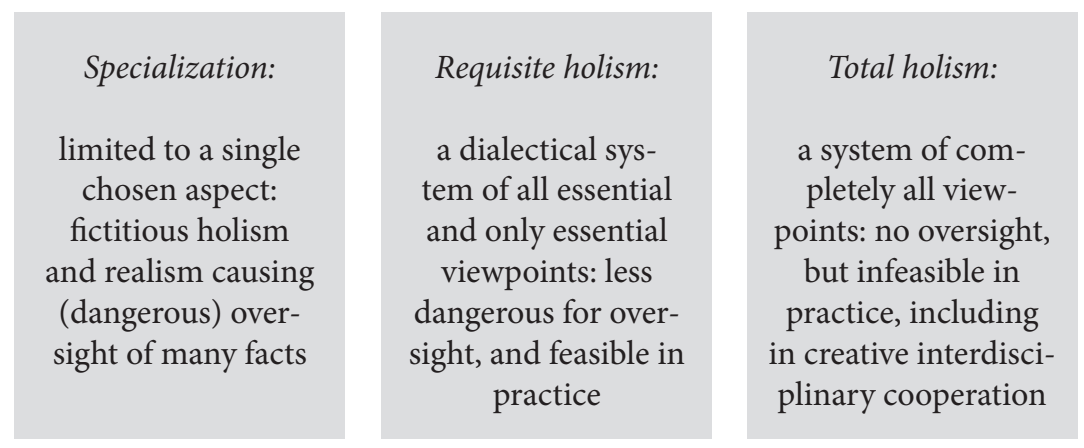

Figure 1. The law of requisite holism of approach

Among the actual characteristics, every specialist puts his/her chosen part of the characteristics of the same subject matter in the centre (e.g. the preschool curriculum). Each choice is important and exact, but only partially so, as it cannot explain the total truth or facts. The dialectical system is difficult to cover in empirical studies for methodological reasons; it is, however, possible (Čančer \& Mulej, 2010). We could find no sources covering the present subject matter. The question remains for future theoretical, methodological, and empirical studies. 


\section{The empirical study}

The study inquired which: 1) educational fields, 2) art genres, and 3) visual arts fields that teaching staff in preschool institutions find more or less important.

\section{Research hypotheses}

H1: Preschool teachers find individual educational fields to be differently important; language, movement, art, nature, society, and maths are not found to be equally important; consequently, education in kindergarten does not achieve the requisite holism.

$\mathrm{H}_{2}$ : Preschool teachers find individual art genres to be differently important; dance, music, literature, visual arts activities, puppets, drama, and audio-visual activities are not found to be equally important; consequently, artistic actions in kindergarten do not achieve the requisite holism.

$\mathrm{H}_{3}$ : Preschool teachers find individual visual arts activities to be differently important; drawing, painting, sculpting, stamping, spatial designs, and art evaluation are not found to be equally important; consequently, visual arts actions in kindergarten do not achieve the requisite holism.

\section{Methodology}

\section{The research method}

This study is based on the descriptive and causal-non-experimental method.

\section{Research sample, population}

The studied population covers preschool teachers and assistant teachers in Maribor kindergartens (i.e. 231 preschool teachers and 264 assistant teachers, or a total of 495 teaching staff members) (source: Municipality of Maribor, the Social Activities Department; December 2012). The study comprised a random sample of 52 teachers and 51 assistant teachers, or a total of 103 teaching staff members, or $20.8 \%$ of the studied population. Surveying was conducted in November of 2012.

Half of the sample included preschool teachers and the other half assistant teachers. It is expected that almost one half (48.54\%) of the sample completed high school ( $9+4$ years), because this is required for assistant teachers. Denac (2010) established the same. The remaining 51.46\% completed higher 
education (a vocational three-year degree or a bachelor's degree). Two thirds of the respondents have ten or more years of work experience.

\section{Process of data collection}

We prepared a questionnaire. Its first part includes questions on years of service, educational degree and position (preschool teacher, assistant teacher). In the questionnaire's main part, respondents used a 10-point scale to rate the importance of individual aspects of the preschool curriculum; "1" represents the least important and "10" the most important aspect. In the first set of items, respondents rated the importance of educational fields from the Curriculum for Kindergartens (Bahovec et al., 1999): movement, language, art, society, nature, and mathematics. In the second set, they rated individual art genres per activities as determined by the curriculum: visual arts, music, dance, drama, literary, puppet, and audio-visual activities. In the third set, respondents rated the importance of visual arts fields. As the curriculum does not specify these fields, we adopted the prevailing artistic and art didactic experts' views (Berce Golob, 1993; Duh \& Zupančič, 2003): drawing, painting, sculpting, stamping (graphics), spatial design, and the basics of aesthetic evaluation. The same fields are specified in Slovenian compulsory schools' syllabi. The outline is presented in Figure 2.

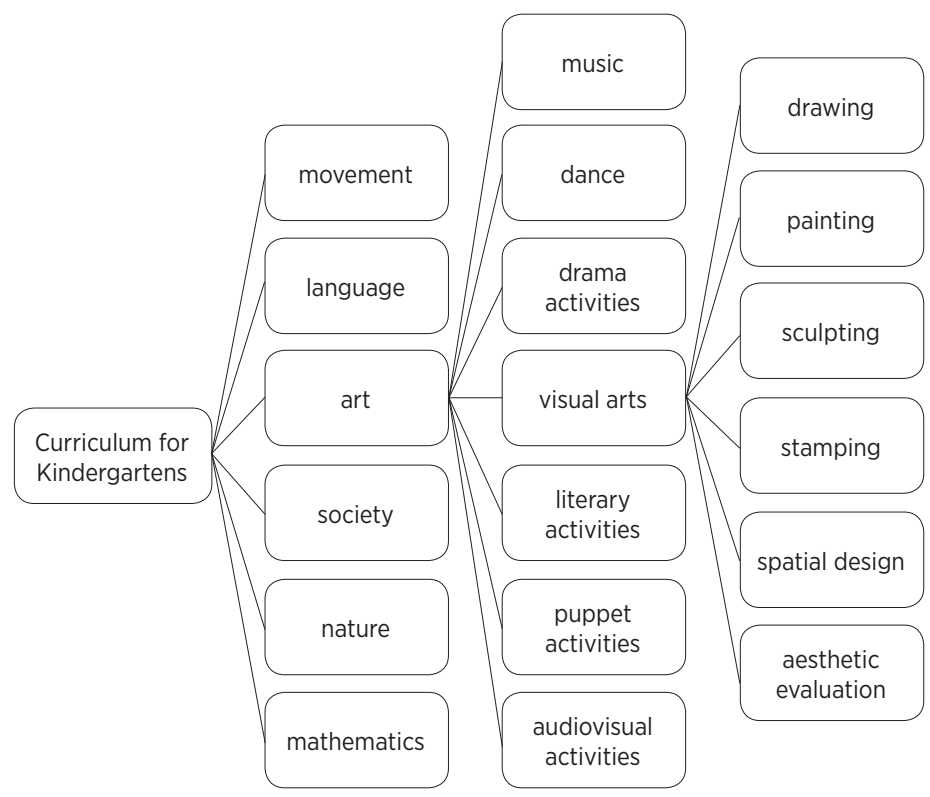

Figure 2. The presence of visual arts fields within art genres and fields of activity in the Slovenian kindergarten curriculum 


\section{Data-processing Procedures}

Data were processed employing the following procedures: frequency distributions ( $\mathrm{f}, \mathrm{f} \%$ ) of categories of the controlled data of the respondents; means $(\bar{x})$ of the levels of importance of individual fields of the curriculum on a 1 to 10 scale; repeated measures ANOVA to test the differences between the curriculum fields' importance; a t-test of differences in rating the importance of curriculum fields related to the degrees of preschool teachers.

\section{Results and discussion}

The results are presented in three chapters; first, analysis of educational fields; second, analysis of art genres; and third, analysis of visual arts fields. Each chapter provides 1) distribution of means of the attributed fields' importance, 2) results of the analysis of differences of importance between fields, and 3) results of the analysis of ratings' differences related to staff's degrees.

Rating of importance of educational fields

Table 1. Educational fields ranked according to the mean attributed importance $(\bar{x})$

\begin{tabular}{lc}
\hline Educational fields & $\overline{\boldsymbol{x}}$ \\
\hline Movement & 9.776 \\
Language & 9.514 \\
Nature & 9.048 \\
Society & 8.893 \\
Art & 8.737 \\
Mathematics & 8.601 \\
\hline
\end{tabular}

Within the scale from 1 to 10, all fields are rated highly (Table 1), which means that teachers find all educational fields to be important. The most important fields are movement and language. These are also the activities most frequently implemented in practice and emphasized by the heads of kindergartens. Mathematics, which appeared in the kindergarten curriculum as an independent educational field only in the year 2000, is perhaps seen as a novelty that is still finding its way into the consciousness of teachers. Table 2 shows whether the differences from Table 1 are statistically significant. 
Table 2. Results of the repeated measures ANOVA testing the differences between six educational fields

\begin{tabular}{lcccc}
\hline \multirow{2}{*}{ Educational fields } & Mean & $\begin{array}{c}\text { Standard } \\
\text { Deviation }\end{array}$ & Wilks' Lambda Test \\
\cline { 2 - 5 } & $\overline{\boldsymbol{x}}$ & $\boldsymbol{s}$ & $\boldsymbol{F}$ & $\boldsymbol{P}$ \\
\hline Movement & 9.776 & 0.641 & & \\
Language & 9.514 & 0.927 & & \\
Art & 8.737 & 1.357 & & 0,000 \\
Society & 8.893 & 1.328 & & \\
Nature & 9.048 & 1.240 & & \\
Mathematics & 8.601 & 1.437 & & \\
\hline
\end{tabular}

The results of the Wilks' Lambda multivariate test show a statistically significant difference in importance $(\mathrm{P}=0.000)$ of educational fields. This confirms the hypothesis $\left(\mathrm{H}_{1}\right)$ that teachers find educational fields to be differently important, which endangers the implementation of the requisite holism in education. Table 3 shows the differences between pairs of fields.

Table 3. Results of the Bonferroni test for pairs of educational fields

\begin{tabular}{llcc}
\hline Educational fields & & $\overline{\boldsymbol{x}}_{1}-\overline{\boldsymbol{x}}_{2}$ & $\boldsymbol{P}$ \\
\hline \multirow{3}{*}{ Movement } & Language & 0.262 & 0.126 \\
& Art & 1.039 & 0.000 \\
& Society & 0.883 & 0.000 \\
& Nature & 0.728 & 0.000 \\
& Mathematics & 1.175 & 0.000 \\
\hline \multirow{4}{*}{ Language } & Art & 0.777 & 0.000 \\
& Society & 0.621 & 0.000 \\
& Nature & 0.466 & 0.016 \\
& Mathematics & 0.913 & 0.000 \\
\hline \multirow{2}{*}{ Art } & Society & -0.155 & 1.000 \\
& Nature & -0.311 & 0.209 \\
& Mathematics & 0.136 & 1.000 \\
\hline \multirow{2}{*}{ Society } & Nature & -0.155 & 1.000 \\
& Mathematics & 0.291 & 0.485 \\
\hline & Mathematics & 0.447 & 0.000 \\
\hline
\end{tabular}


The majority (9) of the pairs of educational fields show statistically significant differences concerning their attributed importance. The fields of movement and language stand out. There is no statistically significant difference between them, but they are statistically more important than the other fields (art, society, nature, and mathematics). Nature has a statistically higher rating than mathematics. Art's, society's and nature's importance are rated similarly. The results coincide with (unfortunately, still occasionally present) the views of educational fields that we can see in practice. Movement and living in nature and the development of language skills are important fields that enable the child's healthy development and present a basis for a successful life. Art is seen as a fun activity whose task is to relax the child. Society and nature are important but not as important as language and movement, while maths should be taught in school. Perhaps the terms that are used to denote these activities partially contribute to this, as the Slovenian preschool curriculum took over the terminology from school subjects (mathematics) and a different view of this activity might be reflected by a different term, e.g. numeracy (Ministry of Education, 2012). The holistic approach to a child's development and learning should be emphasized and to a greater extent included in their subjects by teachers of educational fields in preschool teacher training programmes.

\section{Rating the importance of art genres}

Teachers rated the importance of seven art genres as defined by the Slovenian Curriculum for Kindergartens: visual arts, music, dance, audio-visual, drama, puppets, and literature (Table 4).

Table 4. Art genres ranked according to the mean attributed importance $(\bar{x})$

\begin{tabular}{lc}
\hline Art genres & $\overline{\boldsymbol{x}}$ \\
\hline Visual arts & 9.194 \\
Music & 9.019 \\
Literature & 9.010 \\
Dance & 8.301 \\
Puppet & 8.078 \\
Drama & 7.534 \\
Audio-visual & 6.709 \\
\hline
\end{tabular}

Compared to educational fields (Table 1), the average attributed importance of art genres is lower. Visual arts activities were ranked the highest, followed by music and literary activities, while dance and puppet activities follow 
and were both attributed average importance. Drama activities and audio-visual activities were ranked the lowest. It can be assumed, on the basis of this attributed importance, that among the art genres, visual arts (drawing, painting), music (singing, listening), and literature (listening to stories, storytelling) activities prevail in practical work in kindergartens. The low ranking of puppet activities was surprising, as all preschool didactics view the puppet as an ideal didactic means to be used in diverse situations. Audio-visual activities were found to be the least important, which (similar to mathematics) can be attributed to the fact that these are newer to the curriculum. Table 5 provides the results of verifying the statistical significance of the differences between the covered art genres.

Table 5. Results of the repeated measures analysis ANOVA testing the differences between seven art genres

\begin{tabular}{lcccc}
\hline \multirow{2}{*}{ Art genres } & Mean & Standard Deviation & \multicolumn{2}{c}{ Wilks' Lambda Test } \\
\cline { 2 - 5 } & $\overline{\boldsymbol{x}}$ & $\boldsymbol{s}$ & $\boldsymbol{F}$ & $\boldsymbol{P}$ \\
\hline Visual arts & 9.194 & 1.067 & & \\
Music & 9.019 & 1.221 & & \\
Dance & 8.301 & 1.526 & & 0.000 \\
Audio-visual & 6.709 & 1.829 & 41.758 & \\
Drama & 7.534 & 1.656 & & \\
Puppet & 8.078 & 1.724 & & \\
Literary & 9.010 & 1.264 & & \\
\hline
\end{tabular}

There are statistically significant differences in the ratings of the importance of the covered art genres $(\mathrm{P}=0.000)$. The hypothesis $\left(\mathrm{H}_{2}\right)$ is thus confirmed. Teachers, therefore, also find art genres to be differently important. These are their chosen views, and the realization is subjective. Consequences include differences in children's knowledge and values, perhaps even long-term ones. Table 6 shows the results of the analysis of differences among all seven pairs of art genres. 
Table 6. Results of the Bonferroni test for pairs of art genres

\begin{tabular}{llcc}
\hline Art genres & Activities & $\overline{\boldsymbol{x}}_{1}-\overline{\boldsymbol{x}}_{2}$ & $\boldsymbol{P}$ \\
\hline \multirow{4}{*}{ Visual arts } & 0.175 & 1.000 \\
& Music & $0.894^{*}$ & 0.000 \\
& Dance & $2.485^{*}$ & 0.000 \\
& Audio-visual & $1.660^{*}$ & 0.000 \\
& Drama & $1.117^{*}$ & 0.000 \\
& Puppet & 0.184 & 1.000 \\
\hline \multirow{4}{*}{ Music } & Literary & $0.718^{*}$ & 0.000 \\
& Dance & $2.311^{*}$ & 0.000 \\
& Audio-visual & $1.485^{*}$ & 0.000 \\
& Drama & $0.942^{*}$ & 0.000 \\
& Puppet & 0.010 & 1.000 \\
\hline \multirow{4}{*}{ Dance } & Literary & $1.592^{*}$ & 0.000 \\
& Audio-visual & $0.767^{*}$ & 0.000 \\
& Drama & 0.223 & 1.000 \\
& Puppet & $-0.709^{*}$ & 0.000 \\
\hline \multirow{4}{*}{ Audio-visual } & Literary & $-0.825^{*}$ & 0.000 \\
& Drama & $-1.369^{*}$ & 0.000 \\
& Puppet & $-2.301^{*}$ & 0.000 \\
\hline \multirow{2}{*}{ Drama } & Literary & $-0.544^{*}$ & 0.002 \\
& Puppet & $-1.476^{*}$ & 0.000 \\
\hline & Literary & -0.932 & 0.000 \\
\hline & Literary & &
\end{tabular}

There are only four pairs of art genres for which no statistically significant differences were found. The first three are visual arts activities and music, visual arts activities and literary activities, and music and literary activities. The surveyed teachers attribute the highest importance to these genres (Table 4). The difference between the pairs of dance and puppet activities is also not statistically significant. To all other art genres, statistically significant different importance is attributed $(\mathrm{P}<0.001)$. Visual arts activities are ranked higher than dance, audio-visual, drama, and puppet activities. Music is ranked higher than dance, audio-visual, drama, and puppet activities. Dance is ranked higher than audio-visual and drama, but lower than literary activities. Audio-visual activities are ranked lower than drama, puppet, and literary activities, while drama activities are ranked lower than puppet and literary activities, and puppet activities are ranked lower than literary activities. 
Rating the importance of visual arts fields

Teachers also rated the importance of individual visual arts fields: drawing, painting, stamping, sculpting, spatial design, and art evaluation (Table 7).

Table 7 . Visual arts fields ranked according to the mean attributed importance $(\bar{x})$

\begin{tabular}{lc}
\hline Visual art fields & $\overline{\boldsymbol{X}}$ \\
\hline Drawing & 9.495 \\
Painting & 9.379 \\
Aesthetic evaluation & 8.476 \\
Spatial design & 7.990 \\
Stamping & 7.981 \\
Sculpting & 7.845 \\
\hline
\end{tabular}

Teachers rate drawing and painting as the most important; aesthetic evaluation is also rated high. Spatial design, stamping, and sculpting were attributed a slightly lower average importance $(<8)$. These facts match the directions of art didactics and the prevailing practices in Slovenian kindergartens. Drawing best develops the child's visual perceptions and should be used the most frequently. Painting is an activity that (in addition to drawing) is used the most frequently in kindergartens, partially because the necessary materials (coloured pencils, crayons, etc.) are easy to use, and partially because of the child's desire and need to express him/herself with colours. The high rating of aesthetic evaluation surprizes us. As these activities are connected with visits to galleries and in-depth artistic knowledge, Slovenian preschool teachers avoided them in the past. The development of aesthetic feeling is however integral to requisitely holistic visual arts education, so this result of the study is positive. Table 8 shows the statistical significance of differences between individual visual arts fields.

Table 8. Results of the repeated measures ANOVA testing the differences between six visual arts fields

\begin{tabular}{lcccc}
\hline \multirow{2}{*}{ Visual art fields } & Mean & Standard Deviation & \multicolumn{2}{c}{ Wilks' Lambda Test } \\
\cline { 2 - 5 } & $\overline{\boldsymbol{x}}$ & $\boldsymbol{s}$ & $\boldsymbol{F}$ & $\boldsymbol{P}$ \\
\hline Drawing & 9.495 & 0.906 & & \\
Painting & 9.379 & 0.755 & & \\
Stamping & 7.981 & 1.726 & & \\
Sculpting & 7.845 & 1.655 & 23.375 & 0.000 \\
Spatial design & 7.990 & 1.671 & & \\
Aesthetic evaluation & 8.475 & 1.513 & & \\
\hline
\end{tabular}


The Wilks' Lambda multivariate test shows a statistically significant difference $(\mathrm{P}=0.000)$ between the covered visual arts fields. On this basis, the hypothesis $\left(\mathrm{H}_{3}\right)$ can be confirmed. The statistically significant differences of visual arts fields, as rated by preschool teachers, are professionally more justified, as drawing is the fundamental visual arts field that serves as a basis for all others. Nevertheless, the application of visual arts fields should be more harmonized in kindergartens in order to achieve the requisitely holistic children's development. Even more could be gained from their intertwining, such as an attempted sculpture based on a child's drawings. This applies not only to visual arts but also to other art fields, such as music (Sicherl Kafol, 2001). Table 9 shows the results of the analysis of differences between pairs of visual arts fields.

Table 9. Results of the Bonferroni test for pairs of visual arts fields

\begin{tabular}{llcc}
\hline Visual art fields & Activities & $\overline{\boldsymbol{x}}_{1}-\overline{\boldsymbol{X}}_{2}$ & $\boldsymbol{P}$ \\
\hline \multirow{2}{*}{ Drawing } & Painting & 0.117 & 1.000 \\
& Stamping & $1.515^{*}$ & 0.000 \\
& Sculpting & $1.650^{*}$ & 0.000 \\
& Spatial design & $1.505^{*}$ & 0.000 \\
& Aesthetic evaluation & $1.019^{*}$ & 0.000 \\
\hline \multirow{2}{*}{ Painting } & Stamping & $1.398^{*}$ & 0.000 \\
& Sculpting & $1.534^{*}$ & 0.000 \\
& Spatial design & $1.388^{*}$ & 0.000 \\
& Aesthetic evaluation & $0.903^{*}$ & 0.000 \\
\hline Stamping & Sculpting & 0.136 & 1.000 \\
& Spatial design & -0.010 & 1.000 \\
& Aesthetic evaluation & -0.495 & 0.091 \\
\hline \multirow{2}{*}{ Sculpting } & Spatial design & -0.146 & 1.000 \\
& Aesthetic evaluation & $-0.631^{*}$ & 0.002 \\
\hline
\end{tabular}

Pairs of visual arts fields with a statistically significant difference prevail again. Drawing is rated as statistically significantly more important than stamping, sculpting, spatial design, and art evaluation. Painting is found to be more important than stamping, sculpting, spatial design, and art evaluation. Sculpting and spatial design are evaluated lower than stamping and spatial design, stamping and art evaluation, and sculpting and spatial design. The results indicate a relation between the technical complexity of the implementation of an activity and the frequency of such implementation in working with children. 
Less demanding art techniques are used in drawing and painting (pencil, crayons, etc.), while stamping or spatial design require more complex technical procedures. Preschool teachers feel less qualified to implement these activities. These results also indicate the need for a more holistic approach within the framework of art subjects during study years (Morley, 2014).

\section{Conclusions}

This empirical study, which addressed a random sample of preschool teachers and assistant teachers, revealed their perception of the importance of educational fields, art genres, and visual arts. The following basic results were obtained:

- As regards educational fields in kindergartens, the greatest importance, which is statistically significantly higher than others, is attributed to movement and language. Nature, science, and art are attributed a similar, but slightly lower importance; mathematics has the lowest average attributed importance.

- $\quad$ As regards art genres in kindergartens, visual arts, music, and literary activities are art genres without statistically significant differences; they are rated statistically significantly higher than others (i.e. dance, puppet and drama activities). Audio-visual activities have the lowest average attributed importance.

- Among visual arts fields, drawing and painting are rated the highest. There is no statistically significant difference between them; they are rated statistically significantly higher than the other visual arts fields. Spatial design, stamping, and sculpting enjoy a lower average attributed importance; there is no statistically significant difference between them. Art evaluation, however, is rated statistically significantly higher than any of them, $(\mathrm{P}<0.05)$, or with a tendency to be higher $(0.05<\mathrm{P}<0.10)$.

We, therefore, propose the following:

- The intertwining of activities should be researched in future theoretical, methodological, and empirical studies about preschool education. The requisite holism of preschool education might be excessively left to the requisite personal holism of teachers, their heads, assistants, and parents.

- $\quad$ The values, which education on all three levels provide to teachers, and their practical experience confirms, meet the modern needs for children to be creative. 
- $\quad$ One may hope that these values will soon be transferred from the preschool to the school phase of shaping children's personalities. Children are entering an innovative society and economy where creativity offers many more possibilities than passivity. Memory and knowledge no longer suffice.

- Furthermore, creativity enables both material and psychological prosperity and well-being, which, because of modern technologies, is becoming a condition for success.

\section{References}

Addison, N., Burgess, L., Steers, J., \& Trowell, J. (Eds.) (2010). Understanding Art Education. London and New York: Routledge.

Arnheim, R. (2009). Art and visual perception: a psychology of the creative eye. Berkeley: University of California Press.

Bahovec, E. D., Bregar Golobič, K., Kranjc, S., Cvetko, I., Marjanovič Umek, L., Videmšek, M., Vonta, T., \& Japelj Pavešič, B. (1999). Kurikulum za vrtce [Curriculum for Kindergartens]. Ljubljana: Ministrstvo za šolstvo in šport. Retrieved 10 February 2015, from http://www.mizs.gov.si/fileadmin/ mizs.gov.si/pageuploads/podrocje/vrtci/pdf/vrtci_kur.pdf Berce Golob, H. (1993). Likovna vzgoja [Art education]. Ljubljana: DZS.

Bose, K. (2010). The Issue of Holistic Development of Young Children in ECE Centres of Botswana. Literacy Information and Computer Education Journal (LICEJ), 1(2), 87-94.

Bračun Sova, R., \& Kemperl, M. (2012). The Curricular Reform of Art Education in Primary School in Slovenia in Terms of Certain Components of the European Competence of Cultural Awareness and Expression. CEPS Journal, 2(2), 71-90.

Butina, M. (1997). O slikarstvu [On painting]. Ljubljana: Debora.

Čančer, V., \& Mulej, M. (2010). The Dialectical Systems Theory’s Capacity for Multi-Criteria

Decision-Making. Systems Research and Behavioral Science, 27(3), 285-300.

Denac, O. (2010). Teoretična izhodišča načrtovanja glasbene vzgoje v vrtcu [Theoretical Starting Points for Planning Music Education in Kindergarten]. Ljubljana: Debora.

Devarakonda, C. (2013). India: Early Child Educators in Changing Patterns of Early Childhood Education and Care. In J. Georgeson \& J. Payler (Eds.), International Perspectives on Early Childhood Education and Care (pp. 114-123). Maidenhead, Berkshire: Open University Press.

Didek, Z. (1982). Raziskovanje oblikotvornosti [Researching Design]. Ljubljana: DDU Univerzum. Duh, M., \& Zupančič, T. (2003). Likovna vzgoja v prvi triadi devetletne osnovne šole [Visual Arts in the First Triad of the Nine-Year Primary School]. Ljubljana: Rokus.

Efland, A. D. (2002). Art and cognition: Integrating the visual arts in the curriculum. New York: Teachers College Press.

Eisner, E. W. (2002). The Arts and the Creation of Mind. New Haven: Yale University Press. 
Garvis, S., \& Pendergast, D. (2011). An investigation of early childhood teacher self-efficacy beliefs in the teaching of arts education. International Journal of Education \& the Arts, 12(9), 1-15. Retrieved 10 February 2015, from http://www.ijea.org/v12n9/v12n9.pdf

Herne, S., Cox, S., \& Watts, R. (Eds.) (2009). Reading in Primary Art Education. Bristol, UK, Chicago, USA: Intellect.

Hickman, R. (Ed.) (2008). Research in Art \& Design Education. Bristol, UK: Intellect.

Hickman, R. (2010). Why We Make Art And Why is it Taught. Bristol, UK: Intellect.

Ivon, H., \& Kuščević, D. (2013). School and the Cultural-Heritage Environment: Pedagogical,

Creative and Artistic Aspects. CEPS Journal, 3 (2), 29-50.

Jeffrey, B., \& Craft, A., (2004). Teaching creatively and teaching for creativity: distinctions and relationships. Educational Studies, 30(1), 77-87. doi: 10.1080/0305569032000159750.

Krek, J., Globokar, R., Kalin, J., Kodelja, Z., Pribac, I., \& Šimenc, M. (2011). Uvod. In J. Krek \& M. Metljak (Eds.), Bela knjiga o vzgoji in izobraževanju v Republiki Sloveniji [White book on education in Republic of Slovenia] (pp. 11-62). Ljubljana: Zavod RS za šolstvo.

Krek, J., \& Metljak, M. (Eds.) (2011). Bela knjiga o vzgoji in izobraževanju v Republiki Sloveniji [White book on education in Republic of Slovenia]. Ljubljana: Zavod RS za šolstvo.

Kroflič, R. (2001). Temeljne predpostavke, načela in cilji kurikula za vrtce [The Fundament Assumptions, Principles and Objectives of the Curriculum for Kindergartens]. In L. Marjanovič Umek \& R. Kroflič (Eds.), Otrok v vrtcu [The Child in Kindergarten] (pp. 9-24). Maribor: Založba Obzorja.

Marjanovič Umek, L., Fekonja Peklaj, U., Hočevar, A., \& Lepičnik Vodopivec, J. (2011). Vrtci. In J. Krek \& M. Metljak (Eds.), Bela knjiga o vzgoji in izobraževanju v Republiki Sloveniji [White book on education in Republic of Slovenia] (pp. 63-106). Ljubljana: Zavod RS za šolstvo.

Martin Kniep, G. O., Feige, D. M., \& Soodak, L. C. (1995). Curriculum integration: An expanded idea of an abused idea. Journal of Curriculum and Supervision, 10(3), 227-249.

Morley, S. (2014). Analytic and holistic approaches to Fine Art education: a comparative approach. Journal of Visual Art Practice, 13(2), 101-113.

Kroflič, R. (2007). Vzgojna vrednost estetske izkušnje [Educational value of aesthetic experience]. Sodobna pedagogika, 58(3), 12-31.

Lindstrom, L. (2011). The Multiple Faces of Visual Arts Education. International Journal of Art and Design Education, 3o(1), 7-17.

Ministry of Education. (2012). Nurturing Early Learners - A Curriculum Framework for Kindergarten in Singapore: A Guide for Parents. Singapore: Pre-school Education Branch, Education Services Division, Ministry of Education. Retrieved 25 April 2015, from http://www.moe.gov.sg/education/ preschool/files/kindergarten-curriculum-framework-guide-for-parents.pdf

Mulej, M. (1974). Dialektična teorija sistemov in ljudski reki [The Dialectical system Theory and Proverbs]. Naše gospodarstvo, 21(3-4), 207-212.

Mulej, M. (1979). Ustvarjalno delo in dialektična teorija sistemov [Creative work and the Dialectical Systems Theory]. Celje: Razvojni center. 
Mulej, M., \& Kajzer, Š. (1998). Self-transformation and transition from a preindustrial to contemporary economy and society. In R. G. Dyck \& M. Mulej (Eds.), Self-transformation of the forgotten four-fifths (pp. 325-331). Dubuque: Kendall/Hunt.

Road Map for Arts Education (2006). The World Conference on Arts Education: Building Creative Capacities for the 21st Century. Lisbon, 6-9 March. Retrieved 10 February 2015, from http://www. unesco.org/new/fileadmin/MULTIMEDIA/HQ/CLT/CLT/pdf/Arts_Edu_RoadMap_en.pdf Sicherl-Kafol, B. (2001). Celostna glasbena vzgoja: Srce-um-telo [Holistic music education: heartmind-body]. Ljubljana: Deborah.

Šarotar Žižek, S. (2012). Vpliv psihične blaginje na temelju posameznikove zadostne in potrebne celovitosti na uspešnost (tranzicijske) organizacije [Impact of psychical well-being based on personal requisite holism on success of (transitional) organization]. Maribor: UM, EPF.

UNICEF. (2006). Programming Experiences in Early Child Development. New York: Early Child Development Unit. Retrieved 25 April 2015, from http://www.unicef.org/earlychildhood/files/ programming\%2oexperiences\%20in\%2oearly\%2ochildhood.pdf Zupančič, T. (2008). Likovni kurikul - primerjava konceptov v luči prenove učnega načrta za likovno vzgojo [Art Education Curricula - A comparison of the Concepts Involved in Renovating the Teaching Plan for Art Education]. Revija za elementarno izobraževanje, 1(3-4), 33-44. Zupančič, T. (2012). Ekološka problematika in študenti predšolske vzgoja [Ecological Awareness and Preschool Education Students]. In M. Duh (Ed.), Ekološka in etična zavest skozi edukacijski odnos do narave in družbe [The Ecological and Ethical Awareness through the Educational Attitude towards Nature and Science] (pp. 226-232). Rakičan: Ris Dvorec.

\section{Biographical note}

Dr. Tomaž Zupančıč is currently an Assistant Professor for art education at the Faculty of Education, University of Maribor. He received his $\mathrm{PhD}$ in the field of art educational sciences in 2001 at University of Ljubljana. During 2003-2007 he was the Head of the Department for Preschool Education. His current researches involve postmodern art education principles and contemporary visual art methods and approaches. In the study year 2013/14 he is becoming visiting professor at Estonian Academy of Art (EAA) in Tallinn.

Dr. Branka ČAgran is a Professor of Pedagogical Methodology at the Faculty of Education University of Maribor. She has 29 years of work experience in various fields of pedagogical education. She gained practical experience working as pedagogical counsellor in primary schools, and also in the counselling centre for young children, adolescents and parents. Presently, she is involved in advising university teachers and researchers on research methodology. She has gained her research experience from active participation in experimental and 
non-experimental pedagogical research, and in the evaluation of national and international school projects. She is currently the Head of the Department of Core Pedagogical Subjects.

Dr. (economics, systems theory), Dr. (management, innovation management) Matjaž Mulej is Professor Emeritus, University of Maribor. He is member of three international Academies of Science and Art (Salzburg; Paris; Vienna). He published, mostly with co-authors, about 1.700 contributions in close to 50 countries. He was visiting professor abroad for 15 semesters, including Cornell U., Ithaca, NY. Currently his research addresses social responsibility as a crucial non-technological innovation leading from one-sidedness to systemic behaviour and hence out from the current socio-economic crisis. For details see: izum / cobiss / bibliographies / 08082. 